\title{
Asian Approaches and the Theology of Karl Rahner
}

\author{
Lawrence $\mathrm{Ng}$ \\ Jesuit School of Theology, Santa Clara University, California, US \\ lngyewkim@scu.edu
}

\begin{abstract}
This article explores how Rahner's work can fit within an Asian theological approach of understanding God. For many Asians, religion is a lived experience and being a Christian is a choice that can be counter-cultural. Christianity is still commonly perceived as a Western religion in many parts of Asia. This may result in a re-thinking of what it means to be an Asian Christian beyond the Western context. This article will offer some thoughts on the Asian approach to theology and then consider aspects of Rahner's thought that can appeal to Asian sensibilities. Though Rahner comes from a Western context, there is a commonality in his work, which can speak to the Asian lived faith experience and their orientation towards the divine.
\end{abstract}

\section{Keywords}

Contextual theology, Asian context, Karl Rahner, Mystery, Self-Communication, Transcendental, and Christian life.

\section{INTRODUCTION}

The ground of theology is faith. Without faith, there can be no theology. Theology can then be said to be expressions of one faith and to do theology is also do the work of fides quaerens intellectum. There has been much written over the past decade that speaks of what it means to be a Christian within an Asian context. Asian theologians also speak of an Asian theology as opposed to theology formed from within a Western worldview and culture. The Western worldview since the period of the enlightenment has resulted in a conceptual or substantialist mode of thinking. This may not speak to the context of Asia - from which many 
religious traditions, such as Buddhism and Hinduism, spring forth - that may be resistant to a conceptual way of being or even said to be anti-substantialist. Influences from the Eastern religious traditions may have resulted in the practice of religion in Asia to be more intuitive, with an orientation towards transcendence.

However, this article will argue that there are works from the west that can appeal to Asian sensibilities. They can enlighten a Christian's lived experience of God. One such work is from German theologian Karl Rahner (1904-1984). Rahner speaks of a pre-reflective experience of God and argues that human persons face themselves as a question. The very ground of human persons facing themselves as questions is also the very ground of their transcendence onto the absolute mystery of God.

This article will develop its argument in three parts. First, this article will consider some current conversations of an Asian approach to theology that is distinct from the Western approach. Being a Christian is Asia is sometimes counter-cultural. The decision to be and stay a Christian is a decision, which is grounded by a faith experience.

Second, this leads to this article's contention why Rahner's thought is still relevant, even if his theology was developed within a Western context. There are aspects of Rahner's theology that is orientated around the human person's experience of God and this can relate to the ordinary Asian Christian who must reflect on their faith experiences within the context of their own lives.

Finally, this article will bring to a synthesis on Asian approaches and the work of Rahner. This is possible when one begins from the ground of faith and that theological statements are expressions of faith. In this context, Rahner's work can give words and expressions to their own theological reflections, thereby enriching their faith experiences.

\section{Asian Approaches}

Asia is a complex, pluralistic multicultural society, and each region is with their particular mix of racial and cultural orientations. Christians are small in number, even though the numbers have been growing steadily, such as in China. Philippines is the only country where a majority of the population are Christians. Although it is not easy to speak of an Asian Christianity within the pages of this article, as the views are as diverse as the region itself, it is still possible to draw out some common themes that are uniquely Asian. 
Speaking within the context of Chinese non-Christians, Asian feminist theologian Kwok Pui-Lan states that "many Asian people have a linguistic structure, thought pattern, world-view, and life-style that are radically different from the west." The missionaries who came to China from the seventh century onwards believed that "there is a supreme being, who creates and rules the universe, and God is the name for this 'self-existent, eternal, almighty being, the Creator of heaven and earth." "2 Kwok points out that in contrast to the missionary view, "the Chinese conceive of cosmogony as a dynamic, continuous and organismic process in which there is no creator who stands outside the universe." ${ }^{3}$ She writes this in the context of the view of proclaiming Jesus as God incarnate in China. Kwok states that "since the Chinese do not conceive ultimate reality in the substantive language of 'being', they find it extremely difficult to entertain the thought that God would assume corporal substance or exist in human form." ${ }^{4}$ In Asia, one would find a plurality of underlying thoughts, even if one cannot speak of a concrete worldview like that of the Western approach. In fact, the Buddhist and Hindu view of ultimate reality may have already shape the Asian Christian perception of the divine in many ways.

Jesuit theologian Jose Mario C. Francisco correctly notes that one can find "varying forms of Buddhism, Islam and Christianity that interact with traditions such as Confucianism and Daoism or with local practices like shamanism and indigenous traditions." ${ }^{5}$ Francisco also addressed the view of Christianity as partly foreign, linked to its colonial label. However, Francisco notes that today, to construe Christianity in Asia as the product of imperialism still serves "important political function, 'in contemporary Malaysia and Indonesia, where it can be important, ideologically, to define Christianity as being a foreign intruder." ${ }^{6}$ Working towards re-claiming Christianity as Asian, Francisco points towards

1 Kwok Pui-Lan, "Chinese Non-Christians Perceptions of Christ," in "Any Room for Christ in Asia," ed. Leonardo Boff and Virgil Elizondo, Concilium, no. 2 (1993), 24.

2 Kwok, "Chinese Non-Christians Perceptions," 25.

3 Ibid.

4 Ibid.

5 Jose Mario C. Francisco, "Reclaiming Christianity as Asian," in "Asian Christianities," Daniel Franklin Pilario, Felix Wilfred, and Huang Po Ho, ed, "Asian Christianities," in Concilium, no 1 (2018), 28.

6 Ibid., 29. 
an epistemological decolonization by re-examining or redoing all Asian theology so that one can begin from a new space. In this space, "the fundamental epistemological locus for articulation Asian Christianity lies in the 'lived religion' of Asian Christians, how religion and spirituality are practiced, experienced, and expressed, in their everyday lives." 7

Another Asian theologian who made the distinction between the Western and Eastern approaches is founder and director of the Asian Centre for Cross-Cultural Studies in India, Felix Wilfred, in an article reflecting on the Christian faith and sociocultural rationalities. Wilfred states that a general "theme running through the Western history of theology is that faith does not contradict reason; rather, it enhances and fulfils it." 8 This argument has its roots in "early Christian thinkers who wanted to justify faith as reasonable and reconcile it with the Greek intellectual world." ${ }^{9}$ One would find that "Christianity makes explicit what reason and philosophy have to say about ultimate reality and its becoming self-conscious in humanity." ${ }^{10}$ When Pope John Paul II in Fides et Ratio holds that "faith makes up for the deficiencies and weakness of reason and guides it," the endpoint is clear, which is that "sincere rational enquiry cannot but lead to the fullness or absoluteness of truth which Christian faith offers." ${ }^{11}$

However, Wilfred contends that this is markedly different from the approach in the East because "Asia bases itself on the trans-rational realm of experience (anubhava) as the foundation for the truth of Christianity, rather than try to argue how Christian revelation can be reconciled with the claims of reason." 12 By doing this, Wilfred states that "Asia has tried to interpret Christian faith closer to the early Christian period when experience and witness were points of reference and a litmus

7 Francisco, "Reclaiming Christianity as Asian," 31.

8 Felix Wilfred, "Christian Faith and Sociocultural Rationalities: Reflections from Asia," in "Diverse Cultural and Religious Ways of Thinking: A Dialogue," ed. Theirry-Marie Courau and Carlos Mendoz-Álvarez, Concilium, no. 1 (2017), 104. Wilfred also edited the Oxford Handbook of Christianity in Asia (New York: Oxford University Press, 2014), and is the president of the International Theological Review Concilium.

9 Ibid., 104.

${ }^{10}$ Ibid.

11 Ibid.

12 Wilfred, "Christian Faith Sociocultural Rationalities," 104. 
test for the claims of Christianity." 13 What Wilfred points out is that the "Asian theological reasoning is one that is consonant with the experience of faith as recorded in the Sacred Scriptures, which is different from a reasoning harnessed to elaborate the tenets of faith." 14 This is an important point to consider because the work to relate theology and science is a kind of an extension of seeking to reconcile Christian revelation with the claims of reason, and in this context, with the discoveries of science.

Wilfred points out that the statement of Rig Veda that "truth is one, sages have called it many (ekam sat viprā bahudhā vandanti)" can be the "leitmotiv that runs through the Asian approach to reality as a whole and to the truth of religion in particular." 15 The ways of approaching truth, experiencing it and expressing it in Asian approaches "go beyond discursive thought and conceptual elaborations," because "truth in Asian tradition is never something once and for all given and to be possessed, but something that is to be continuously sought after." 16 The term "journey' is often used to describe something such as 'one's journey', or the 'journey of faith'. In Asian traditions, journey (yatra) is a root metaphor that provides "dynamism and movement in the quest for truth and its deeper experience and understanding." 17 According to Wilfred, this is well expressed in the form of prayer in the ancient Upanishads: "From ignorance, lead me to truth (asato mā sadgamaya), From darkness, lead me to light (tamasomā jyotir gamaya), From death, lead me to immortality (mrityormā amritam gamaya), Om peace, peace, peace (óm shānti shānti shanti)." 18

Returning to the point which started this discussion, the question on bringing the conversations relating the Western approach to theology within the context of Christianity in Asia remains. We have seen that Asians speaks of experience, relationship with God, faith as a journey, and displays a resistance to the Western approach. A positive contribution is still possible when the work to relate these two different approaches by concretely locating it on the ground of one's lived experience and journey of faith of Asians.

${ }^{13}$ Ibid.

14 Ibid.

${ }^{15}$ Ibid., 106.

16 Ibid.

${ }^{17}$ Ibid. Wilfred is speaking from within the cultural context in India.

${ }^{18}$ Ibid. 
When speaking of postcolonial theology and literature, Wilfred says that "it must seek to find its own language and episteme to express the indigenous and contextual experiences challenging the universalist claims of Western theology or classical literature." ${ }^{19}$ Wilfred adds, "The imported theology despite its claims to the contrary, is in fact, limited to the West and hence provincial; it bears clearly the marks of colonialism." ${ }^{20}$ This will not do because this "inherited colonial theology tries to frame the questions with its point of reference, and what is expected of colonized people of Asia, Africa, and Latin America is to respond to the questions already framed." 21 Instead of this, "contextual and postcolonial theologies will frame the questions themselves through their episteme and language and deal with the theological question in context." 22 Taking this as a cue, the relationship between theology and science can be worked by Asian themselves within their own episteme and language. However, to disregard or do away with Western approaches, simply because it is imported theology, may leave Asian Christianity and its work in theology poorer. There is an interesting story about the Dalai Lama that might be relevant to the discussion of this paper.

Matthieu Richard, monk and co-author of The Quantum and the Lotus, described a meeting at Dharamsala, India, where leading psychologists, neuroscientists, philosophers, and specialists in emotions spent a whole week in discussion with the Dalai Lama. ${ }^{23}$ The discussion took a decisive turn towards a new field of research, "contemplative neuroscience," when the Dalai Lama remarked, "All these discussions are

19 Felix Wilfred, "Asian Christianities and Theologies through the Lens of Postcolonialism," in “Asian Christianities," Daniel Franklin Pilario, Felix Wilfred, and Huang Po Ho, ed, "Asian Christianities," in Concilium, no 1 (2018), 19.

20 Ibid.

21 Wilfred, "Asian Christianities and Theologies, 19.

22 Ibid.

23 Matthieu Ricard and Xuan Thuan Trinh, The Quantum and the Lotus: A Journey to the Frontiers Where Science and Buddhism Meet, 1st American ed. (New York: Crown Publishers, 2001). It should be interesting to note that Ricard has a Ph.D. degree in molecular genetics at the Pasteur Institute under French Nobel Laureate François Jacob. After completing his doctoral thesis in 1972, Ricard decided to forsake his scientific career and concentrate on the practice of Tibetan Buddhism. Ricard, the son of the late French philosopher Jean-François Revel (born Jean-François Ricard), and his mother is the lyrical abstractionist painter and Tibetan Buddhist nun Yahne Le Toumelin. Source: https:// en.wikipedia.org/wiki/Matthieu_Ricard\#cite_note-nydailynews-happiest-man-1. 
very interesting, but what can we really contribute to society?" ${ }^{24}$ Perhaps theologians can take their que from the statement by the Dalai Lama and ask how their work can contribute to society?

\section{The Theology of Karl Rahner: Beginning With Ourselves as Questions}

Rahner's teaching can be said to be ecclesiological in nature and in many places, Rahner tried to illuminate the dogmatic teachings of the Church in light of Vatican II. However, what is on interest to this article which can contribute to an Asian's own expression of faith is Rahner's view of the human person who stands before the ground of the absolute mystery who is God.

Rahner's starting point is to see the human person as a question: "We must reflect first of all upon man as the universal question which he is for himself." ${ }^{25}$ When the human person faces themselves as a question, then that "creates the condition of really hearing, and the only answer brings the question to its reflective self-presence." ${ }^{26}$ In Spirit in the World, Rahner writes, "Man questions. This is something final and irreducible... Man questions necessarily... this necessity can only be grounded in the fact that being is accessible to man at all only as something questionable [Fragbarkeit], that he himself is insofar as he asks about being, that he himself exists as a question about being." 27

For the human person, to question is as essential as breathing. However, questioning does not bring the person outside of himself or herself but, rather, within. Rahner writes, "The question about being as a transcendental question consciously turns upon itself, looks and questions itself, it reveals itself as a knowledge of man about his questioning essence: he is already with being in its totality (beim Sein im ganzen): otherwise, how could he ask about it?" 28 The human person is then able to recognize a broader context within which the question has been asked

${ }^{24}$ Maurice Ricard, "Inner Expereince and Neuroscience," in “Theology, Anthropology and Neuroscience," ed. Theirry-Marie Courau, Regina Ammicht Quinn, Hille Haker \& Marie-Theres Wacker, Concilium, no. 4 (2015) 15-25.

${ }^{25}$ Rahner, Foundations of Christian Faith, 11.

${ }^{26}$ Ibid.

${ }^{27}$ Karl Rahner, Spirit in theWorld, trans. William Dych (New York: Continuum, 1994), 57.

${ }^{28}$ Ibid. 
and is open to "more" reality. ${ }^{29}$ It is in the "act of knowing any particular thing, the human being is already 'beyond' this immediate object and has an awareness of the whole range of possible objects, or being as such." 30 Rahner writes,

In his first question (which always takes place with the question of being as its ground) he is already quodamodo omnia (in a certain way everything), and still he is not yet that, he is still nothing, 'tabula rasa, materia prima in ordine intellectus' (a clean slate, prime matter in order of intellect), for precisely what he does is ask what he means when he asks about being in its totality. ${ }^{31}$

A person, "insofar as he experiences himself as conditioned and limited by sense experience, and all too much conditioned and limited, he has already transcended this sense experience." 32 The transcendence of the human person is "always orientated towards the holy mystery." ${ }_{3}$ It is by this that the questioning human person experiences his or her finiteness and "reaches beyond this finiteness and experiences himself a transcendent being, as spirit," as a "being with an infinite horizon." ${ }_{34}$ Rahner writes that "the infinite horizon of human questioning is experienced as a horizon which recedes further and further the more answers man can discover." 35 This transcendental experience, the being "whom we call 'God' encounters man in silence, encounters him as the absolute and the incomprehensible." 36

\section{Transcendence and the Self-Communication of God}

The human person is wrapped in the absolutely incomprehensible mystery whom we call God. Harvey D. Egan writes that "theology, for Rahner, must always be salvific, that is, focused on God's forgiving, heal-

29 Gregory Brett, The Theological Notion of the Human Person: A Conversation Between the Theology of Karl Rahner and the Philosophy of John Macmurray (New York: Peter Lang, 2013), 52.

30 Ibid.

31 Rahner, Spirit in theWorld, 60

32 Rahner, Foundations of Christian Faith, 20.

33 Ibid., 21.

34 Ibid., 32.

35 Ibid.

36 Ibid. 
ing, and transforming love as revealed in the long history of salvation which reached its high point in the life, death, and resurrection of Jesus Christ." ${ }^{37}$ Hence, Rahner views Christianity as simply "nothing more than the genuine explication and true interpretation of what resides in the ultimate depth of the human person." ${ }^{38}$ In essence, "because Christianity is the best interpretation of what and who we are, Rahner grounded his theology in God's unending self-revelation in human experience manifested in the life, death, and resurrection of Jesus Christ." 39 Thus, for Rahner, the ground of the finiteness that human beings experience is the very ground by which they transcend. When reading Rahner, "one is sure to come across the term transcendental, and in many disguises." ${ }^{40}$ Rahner is "described as a transcendental Thomist and as a proponent of transcendental theology." ${ }^{41}$ Rahner speaks of "transcendental experience, transcendental revelation, human transcendence or transcendentality, of transcendental investigations, and of transcendental anthropology." 42 In Rahner's thought, "to transcend means to surpass, to go beyond or above, and one might expect 'transcendental' to have something to do with that which goes beyond or rises above something." ${ }^{43}$

It is because that the transcendence of the human person is always orientated towards the holy mystery, which "explains why our questions never cease, why we eventually must ask ultimate questions, and why we are never satisfied totally with anything in this life." 44 For Rahner, mystery is "the horizon which cannot be mastered and which masters all of our understanding, and which allows the other to be understood by being present to itself in its silence and in its incomprehensibility." ${ }^{45}$ This relates to Rahner's view on the transcendental nature of human beings,

37 Harvey D. Egan, "Theology and Spirituality," in The Cambridge Companion to Karl Rahner, ed. Declan Marmion and Mary E. Hines (2005; repr., New York: Cambridge University Press, 2007), 14.

38 Ibid.

39 Ibid.

40 Karen Kilby, Karl Rahner:Theology and Philosophy (New York: Routledge, 2004), 32.

41 Ibid.

42 Ibid.

43 Ibid.

44 Egan, "Theology and Spirituality," 19.

45 Rahner, Foundations of Christian Faith, 217. 
which is very much at the heart of his theology. Rahner states, "Man [as a being is] mystery in his essence, his nature... beings who are referred to the incomprehensible God. But this reference, which is our nature, can only be conceived and understood when we allow ourselves freely to be grasped by the incomprehensible." 46 Thus, Rahner believes that "our whole existence is the acceptance or rejection of the mystery which we are, as we find our poverty referred to the mystery of the fullness." ${ }^{47}$ In this respect, mystery is not something to be discovered so that it ceases to be a mystery. Instead, "mystery is our nature, because the transcendence which we are and which we accomplish brings our existence and God's existence together: and both as mystery." 48

A significant point for Rahner in his anthropology is his use of the transcendental pre-apprehension (Vorgriff) of being. On this, Rahner states that "man is a transcendent being insofar as all of his knowledge and all of his conscious activity is grounded in a pre-apprehension of 'being' as such, in an unthematic but ever-present knowledge of the infinity of reality." ${ }^{49}$ Rahner constructs this concept based on earlier conceptions. Karen Kilby explains the concept of Vorgriff by explaining the sources from which Rahner drew:

To characterize the Vorgriff, and its relation to our knowledge or choice of particulars, Rahner relies on a number of images. One is taken from Heidegger: we are aware of infinite being as the horizon for our knowledge of finite things. An awareness of being and of God, to put it another way, forms the ever-present and necessary background for our knowledge of the particular objects that lie in the foreground of consciousness. A second image is borrowed from (though not original to) Aquinas: the Vorgriff is the light which in illuminating the individual objects allows our intellect to grasp them. A third image, that of movement, Rahner owes chiefly to Maréchal: we have a dynamism towards being and God, so that the mind always moves beyond any particular, never entirely satisfied or at rest. ${ }^{50}$

46 Karl Rahner, "On the Theology of the Incarnation.” in Theological Investigations, vol. 4, More RecentWritings, trans. Kevin Smyth (London: Darton, Longman, 1966), 108.

47 Ibid., 109.

48 Rahner, "Theology of the Incarnation.” 109.

49 Rahner, Foundations of Christian Faith, 33.

50 Kilby, Karl Rahner, 20. 
The expression 'mind always moves beyond any particular' can be understood in the sense that we transcend ourselves even in our thinking. This speaks to Rahner's point about the human person as a transcendent being. Kilby notes, "Rahner is always careful to insist, not to confuse the kind of awareness we have of being and of God with our knowledge of finite objects." ${ }^{51}$ At least the first two of the three images that characterize Rahner's use of Vorgriff can help us make the distinction between the two kinds of knowing. Rahner contextualized these earlier conceptions to give expressions on how he saw the experience of the human person who stands and yet is also orientated towards the mystery of God.

Rahner says that in order "to determine the breadth of the horizon" that we want to pre-apprehend, the question to ask is this: "Is this horizon that of the imagination of infinite space and time, or is it broader, in principle unlimited in every dimension, the horizon of being absolutely, which discloses itself as transcending space and time?"52 The nature of this pre-apprehension is not in the "object of human knowledge," because it would mean that our pre-apprehension would be "conditioned by another pre-apprehension." ${ }_{33}$ Rahner tells us that "this 'wither' (Worauf) of the pre-apprehension as such is not a humanly conceivable object." 54 Pre-apprehension is a way that we understand human knowledge but "pre-apprehension goes beyond what is 'grasped." 55 Pre-apprehension is, then, not just about what can be grasped or about the attainment of human knowledge, but rather it is the act of pre-apprehending itself that moves us "towards the totality of the object." ${ }^{6}$

Finally, the aspect of Rahner's understanding of self-communication is important as his thoughts of human persons facing themselves as questions and are orientated towards the holy mystery. God's self-communication is not merely God speaking in a language that the human person can understand. In God's self-communication, what is "communicated is really God in his own being, and in this way it is a communication for the sake of knowing and possessing God in immediate vision

${ }^{51}$ Ibid.

52 Rahner, Spirit in theWorld, 143.

${ }^{53}$ Ibid.

${ }^{54}$ Ibid.

${ }^{55}$ Ibid., 143-144.

${ }^{56}$ Ibid., 145. 
and love." 57 In other words, "the giver is the gift given." ${ }^{58}$ Rahner writes that God's self-communication "has 'divinizing' effects in the finite existent in whom this self-communication takes place." ${ }^{59}$ For Rahner, grace "is first and foremost God in self-communication." ${ }^{0}$ Grace is something accessible to everyone, and it is the heart of one's existence. Grace is not elusive as grace is present in one's relationship with God. If grace is the self-communication of God, then this self-communication is addressed to all creation. In his Theological Investigations essay "Theology and Anthropology," Rahner explains grace from a transcendental anthropological framework:

Grace is God himself in self-communication, grace is not a 'thing' but - as communicated grace - a conditioning of the spiritual and intellectual subject as such to a direct relationship with God... it can only be understood from the point of view of the subject, with his transcendental nature, experienced as a being-in-reference-to the reality of absolute truth and free-ranging, infinite, absolutely valid love. It can only be understood in one's innermost regions as an immediacy before the absolute mystery of God, i.e. as the absolute realization of man's transcendental nature itself, made possible by God in his self-communication. ${ }^{61}$

Thus, "grace is neither detraction from, nor alien addition to, the authentically human, but fulfillment of the openness to the mystery energizing the heart's drive to self-realization. Grace is ground, polestar, and goal of the human journey." 62 Therefore, all truly human activity is a free, positive or negative, response to God's offer of self-the grace at the heart of human existence. Because God offers nothing less than God's very own self to everyone, the human person is, to Rahner's way of thinking, homo mysticus, a mystical person. ${ }^{63}$

57 Rahner, Foundations of Christian Faith, 118.

58 Stephen J. Duffy, “Experience of Grace,” in Marmion and Hines, 44.

59 Rahner, Foundations of Christian Faith, 120.

60 Duffy, "Experience of Grace," 44.

${ }^{61}$ Karl Rahner, “Theology and Anthropology," in Theological Investigations, vol. 9, Writings of 1965-67 1, trans. Graham Harrison (London: Darton, Longman and Todd, 1972), 36-37.

${ }^{62}$ Duffy, "Experience of Grace," 45.

${ }^{63}$ Harvey D. Egan, “The Mystical Theology of Karl Rahner,” The Way 52, no. 2 (April 2013): 43 . 


\section{On the Christian Life}

Rahner locates the human person, who is a mystical person within the aspects of living a Christian life within the realities of the world. It is not the sacraments that ultimately defines a Christian but the total acceptance of oneself as one is and in the reality of the condition they find themselves in. This total acceptance leads to a life of freedom. For Rahner, "freedom is ultimately an openness to everything, to everything without exception: openness to absolute truth, to absolute love, and to the absolute infinity of human life in its immediacy to the very reality we call God." ${ }^{4}$ A Christian is one who is truly realistic about who and where they are, even as they stand before God. It is in this context that Rahner describes the Christian life as characterized by "pessimistic realism." Thus, "the real and total and comprehensive task of a Christian as a Christian is to be a human being, a human being of course whose depth is divine." 65

Rahner is not telling Christians to be pessimistic but to recognize that the realities of life obliges the "Christian to see this existence as dark and bitter and as an unfathomable radical risk." ${ }^{66}$ For example, one cannot ignore that Asia has been plagued by corruption and oppressive leaders seeking personal gains. These affect the quality of life and may result in an unjust situation. It is awareness of the state of things such as these that the Christian can see and "recognized that life is threatened radically in order to grasp what God is and wants for us." ${ }^{67}$ It is within this context too that one can, with hope, leap beyond oneself to the promise of the living God that God will triumph over the risks of human existence with God's powerful love. ${ }^{68}$ Only then the Christian can "believe and hope and grasp God's promises in the good news of Jesus Christ." 69

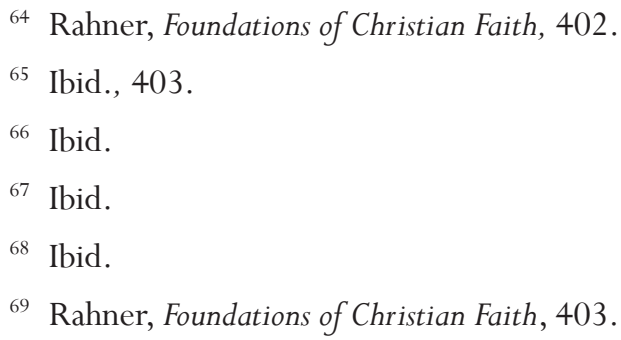




\section{Conclusion: A Common Ground}

Theology, despite its claims, are not universal statements of faith and that it can be applied across the board from the West to the East. Stephen Bevans tells us very persuasively, "There is no such thing as 'theology'; there is only contextual theology: feminist theology, black theology, liberation theology, Filipino theology, Asian-American theology, African theology, and so forth." ${ }^{70}$ Theology "deals with faith and the object of faith," thus "theological statements are statements of faith." 71 Faith is a response and perhaps the only reasonable response to the experience of the divine, which in turn leads to responses of belief, obedience, and love in God. It may be an experience that grows like a seed or suddenly like a big electric jolt, but the result is faith.

It is within the experience of faith that Rahner speaks of a desire to believe with intellectual honesty. By his work, Rahner wants to "give people confidence for the very content of Christian dogma itself that they can believe with intellectual honesty." ${ }^{2}$ To be intellectually honest is to accept that one's faith is, "humanly speaking, always open and provisional, and capable of further development." 73

Rahner's work can be appealing to Asian sensibilities for many reasons. First, Rahner goes beyond harmonizing faith with reason and speaks of faith as a lived experience. An Asian can relate to Rahner's point about the ceaseless question they face about themselves and the world they live in. Rahner tells us that the very ground of these questions is also the ground that created the condition for an openness to they mystery of God. Rahner says that the experience of God comes first. It is a first level unthematic experience of God that allows the possibility of theological experience. A Christian is a reflective person who "reflects upon the whole of his experience." 74 This "totality opens out into the dark abysses of the wilderness which we call God." 75 To do

70 Stephen Bevans, Models of Contextual Theology, rev. ed. (Maryknoll, NY: Orbis Books, 2013), 3 .

71 Roger Haight, Dynamics of Theology (Maryknoll, NY: Orbis Books, 1990), 10.

72 Rahner, Foundations of Christian Faith, 12.

73 Ibid., 57.

74 Rahner, Foundations of Christian Faith, 11.

75 Ibid., 2. 
theology then is to "reflect upon the fundamental assertion of Christianity as the answer to the question which [the human person] is."76

Furthermore, one's faith experiences always take place within the context of one's own culture. It is no easy task to do as Francisco suggests, which is to work towards an epistemological decolonization by re-examining or redoing all Asian theology so that one can begin from a new space. What and where is this new space that one begins from? Even if one begins from the faith experiences of the bible, the letters of Paul are marked by the influence of Greek Culture. The foundational interpretation by the Church Fathers of how one understands Christ, which is now enshrined in the Nicaean creed, is developed within the perspective of Greek philosophy. As was noted earlier, the Asian perspective is not tied to a common worldview and each region is different. Whether or not, one can properly speak of an Asian worldview itself is debatable. Consider Southeast, North, and East Asia itself. The context and practice of faith is vastly different from Thailand, Vietnam, Malaysia, Indonesia, and Japan. For the Catholic faith, what is common is the liturgical celebrations from the Western Roman Missal. Of course, the bible is the common ground for all.

However, despite the differences, all Asian strive toward a deeper and personal relationship with God. In the respect, the idea of a mystic is not far from the mind of an Asian. A simple understanding of a mystic is one who lives with a union with God. As we have seen earlier, the mystical dimension is present and is an important thought in Rahner's theology. Rahner describes mysticism as a "person's experience of his own pure spirituality" and in this context, "it is as provisionally open and ambiguous as all of [the human person's other experiences of [themselves] in an encounter with the living God."77 Mysticism" is "a human's experience of God" and "Christian mysticism is the experiencing of God in Jesus Christ in the light of the Holy Spirit."78 Rahner maintained that Christianity contains a mystical component "because of the immediate unthematic experience of God found within the unlimited breath

76 Ibid., 11.

77 Rahner, "Mysticism.” In Encyclopedia of Theology: A Concise Sacramentum Mundi, ed. Karl Rahner (London: Burns \& Oates, 1971), 1004-1011.

78 Richard P. McBrien, Catholicism: New Study Edition (San Francisco: HarperCollins, 1994), 1250. 
of our consciousness." 79 It is on the grounds that the experience of God is accessible to all persons as a knower in possession of themselves that Rahner states, "The Christian of the future will be a mystic or will not exist at all." 80

Finally, Rahner's description of the call of mystery can be understood today as one's ceaseless journey of faith that never ends while one continues to have breath. It may be difficult to specific concretely this journey of faith within Asian Christianity and its theological expressions. However, one can still speak of a first-person perspective of faith experience. It is in this respect that one may find that Rahner's work can give the words and theological expressions to their own faith experiences.

\section{BiBLIOGRAPHY}

Bevans, Stephen. Models of Contextual Theology. Rev. ed. Maryknoll, NY: Orbis Books, 2013.

Brett, Gregory. The Theological Notion of the Human Person: A Conversation between the Theology of Karl Rahner and the Philosophy of John Macmurray. New York: Peter Lang, 2013.

Duffy, Stephen J. “Experience of Grace.” In Marmion and Hines, 43-62.

Egan, Harvey D. "The Mystical Theology of Karl Rahner." The Way 52, no. 2 (April 2013): 43-62.

—. "Theology and Spirituality." In Marmion and Hines, 13-28.

Francisco, Jose Mario C. "Reclaiming Christianity as Asian.” In "Asian Christianities," Concilium, no. 1 (2018): 27-36.

Haight, Roger. Dynamics of Theology. Maryknoll, NY: Orbis Books, 1990.

Kilby, Karen. Karl Rahner: Theology and Philosophy. New York: Routledge, 2004.

Kwok Pui-Lan, "Chinese Non-Christians Perceptions of Christ." In "Any Room for Christ in Asia," edited by Leonardo Boff and Virgil Elizondo, Concilium, no. 2 (1993): 24-32.

Marmion, Declan, and Mary E. Hines, eds. The Cambridge Companion to Karl Rahner. 2005. Reprint, New York: Cambridge University Press, 2007.

79 Egan, "Theology and Spirituality," 19.

${ }^{80}$ Rahner, "Christian Living Formerly and Today," in Theological Investigations, vol. 7, Further Theology of the Spiritual Life, translated by David Bourke (New York: Herder and Herder, 1971), 15. 
McBrien, Richard P. Catholicism: New Edition. San Francisco: HarperCollins, 1994.

Rahner, Karl. "Christology in the Setting of Modern Man's Understanding of Himself and of His World." In Theological Investigations. Vol. 11, Confrontations, translated by David Bourke, 215-230. London: Darton, Longman and Todd, 1974.

"Christian Living Formerly and Today." In Theological Investigations. Vol. 7, Further Theology of the Spiritual Life, translated by David Bourke, New York: Herder and Herder, 1971.

Rahner, Karl, ed. Encyclopedia of Theology: The Concise Sacramentum Mundi. New York: Seabury Press, 1975.

Rahner, Karl. Foundations of Christian Faith: An Introduction to the Idea of Christianity. New York: Crossroad, 1984.

—. "On the Theology of the Incarnation." In Theological Investigation. Vol. 4, More Recent Writings, translated by Kevin Smyth, 105-120. London: Darton, Longman, 1966.

Rahner, Karl.. Spirit in the World. Translated by William Dych. New York: Continuum, 1994.

—. "Theology and Anthropology." In Theological Investigations. Vol. 9, Writings of 1965-67, translated by Graham Harrison, 28-45. London: Darton, Longman and Todd, 1972.

Ricard, Maurice "Inner Experience and Neuroscience." In "Theology, Anthropology and Neuroscience," edited by Theirry-Marie Courau, Regina Ammicht Quinn, Hille Haker \& Marie-Theres Wacker. Concilium, no. 4 (2015): 15-25.

Ricard, Matthieu, and Xuan Thuan Trinh. The Quantum and the Lotus: A Journey to the Frontiers Where Science and Buddhism Meet. 1st American ed. New York: Crown Publishers, 2001.

Shen, Philip. "Theological Pluralism: An Asian Response to David Tracy." Journal of the American Academy of Religion 53, no. 4 (1985): 735-51.

Wilfred, Felix ."Asian Christianities and Theologies through the Lens of Postcolonialism," edited by Daniel Franklin Pilario, Felix Wilfred, and Huang Po Ho. In "Asian Christianities," Concilium, no 1 (2018): 15-26.

_. "Christian Faith and Sociocultural Rationalities: Reflections from Asia." In "Diverse Cultural and Religious Ways of Thinking: A Dialogue," edited by Theirry-Marie Courau and Carlos Mendoz-Álvarez, Concilium, no. 1 (2017): 101-110. 
"Images of Jesus Christ in the Asian Pastoral Context." In "Any Room for Christ in Asia," edited by Leonardo Boff and Virgil Elizondo, Concilium, no. 2 (1993):51-61. 